\title{
Changes in the Cell Surface of the Dimorphic Forms of Candida albicans by Treatment with Hydrolytic Enzymes
}

\author{
By F. W. CHATTAWAY, S. SHENOLIKAR AND J. O'REILLY \\ Department of Biochemistry, The University, Leeds $L S 2{ }_{9} L S$ \\ AND A. J. E. BARLOW \\ Department of Dermatology, The Royal Infirmary, Huddersfield, Yorkshire
}

(Received 22 January 1976)

\begin{abstract}
SUMMARY
The release of acid phosphatase and polysaccharide-peptide complexes by hydrolytic enzymes from the surface of the blastospore and mycelial forms of Candida albicans has been examined in cells from $4 \mathrm{~h}$ and $\mathrm{I} 8 \mathrm{~h}$ cultures and the results correlated with the appearance of the treated cells in the electron microscope. Treatment with dithiothreitol was necessary for the degradative action of the enzymes to occur. Material released by all the treatments used had a similar qualitative composition, but the proportions of mannan, glucan, peptide and acid phosphatase varied with different treatments and with the type of cell examined. I,3- $\beta$-Glucanase was required for major changes in the cell wall to be effected, but a significant amount of material was released with a chitinase preparation containing some protease activity. Protoplasts were obtained from all types of cell using Cytophaga lytic enzyme $\mathrm{L}_{1}$ which had $\mathrm{I}, 3-\beta$-glucanase and protease activity, but the purified I,3- $\beta$-glucanase and protease prepared from Streptomyces violaceus cultures required the presence of a chitinase before protoplasts were released. The bonding association between the major components which comprise the cell wall, and the spatial distribution of these macromolecules, varies appreciably between the two dimorphic forms and with the age of the culture.
\end{abstract}

\section{INTRODUCTION}

The cell wall of blastospores of Candida albicans is 200 to $300 \mathrm{~nm}$ thick (Gale, 1963), and contains a highly branched glucan with $72 \%$ I,6- $\alpha$ - and $27 \%$ I,3- $\alpha$-linkages (Yu et al., I967a), part of which is closely associated with chitin (Domanski \& Miller, 1968), and mannans with $1,2-\alpha$ - and $1,6-\alpha$-linkages, which are firmly bound to protein (Kessler \& Nickerson, 1959; Yu et al., $1967 b$ ). Less information is available concerning the wall of the mycelial form but Cassone, Simonetti \& Strippoli (1973) found it had a similar structure to that of the blastospore but approximately half the thickness. The glucan, mannan and chitin content appears to be similar in nature to that of the blastospore, but the polysaccharide proportions and the protein composition vary between the two morphological forms in the early-stationary growth phase (Chattaway, Holmes \& Barlow, 1968). These results come from chemical analysis of isolated walls and few attempts have been made to examine the wall structure of Candida using hydrolytic enzymes, although several such studies have been made for Saccharomyces spp. (e.g. McLellan \& Lampen, I968; Bacon et al., 1970).

Exposure of both mycelial and blastospore forms of $C$. albicans to dithiothreitol (DTT) releases saccharide and protein material including acid phosphatase from the cell surface (Chattaway, Shenolikar \& Barlow, 1974). This work has now been extended to study the 
effects of glucanases, chitinase and proteases on the cell surface in the presence of dithiothreitol, by electron microscopy and by the extent of release of these materials from the two morphological forms in $4 \mathrm{~h}$ and $\mathrm{I} 8 \mathrm{~h}$ cultures. The $4 \mathrm{~h}$ cultures contained cells predominantly in the exponential phase of growth when maximum germination of blastospores occurs under suitable environmental conditions. The I $8 \mathrm{~h}$ cultures contained cells predominantly in the early-stationary phase.

\section{METHODS}

The strain (caI) of Candida albicans (Robin) Berkhout used and the methods of maintenance, growth on medium $\mathrm{C}$ and harvesting of blastospores and mycelium, were as described by Chattaway et al. (1968).

Preparation of lytic enzymes

From Streptomyces violaceus. The organism was grown on the medium of Elorza, Ruiz \& Villanueva (1966) for 5 days with chitin $\left(5 \mathrm{~g} \mathrm{l}^{-1}\right)$ as carbon source. The culture filtrate was concentrated and the enzymes precipitated by $90 \%$ saturation with $\left(\mathrm{NH}_{4}\right)_{2} \mathrm{SO}_{4}$. This preparation contained chitinase, endo-I,3- $\beta$-glucanase and protease activities. The enzyme preparation was also stirred with colloidal chitin (Berger \& Reynolds, I958) to remove chitinase, and the supernatant was used as a source of endo-I,3- $\beta$-glucanase and protease. Purified endo-I,3- $\beta$-glucanase free of protease and chitinase (fraction 3, Fig. I) was prepared from culture filtrates in which laminarin $\left(5 \mathrm{~g}^{-1}\right)$ was substituted for chitin as carbon source. The 40 to $60 \%\left(\mathrm{NH}_{4}\right)_{2} \mathrm{SO}_{4}$ fraction was prepared and fractionated on DEAEcellulose (DE52, Whatman) with a gradient of $100 \mathrm{ml} 0 \cdot \mathrm{I} \mathrm{M}-\mathrm{Na}_{2} \mathrm{HPO}_{4}$ and $500 \mathrm{ml} 0.2 \mathrm{M}-$ $\mathrm{NaH}_{2} \mathrm{PO}_{4}$. Figure I shows the presence of several I,3- $\beta$-glucanases and at least two proteases in the original filtrate. All fractions from the column were dialysed against running water until free of inorganic phosphate.

Endo-I,3- $\beta$-glucanase from Cytophaga spp. The Cytophaga lytic enzyme $\mathrm{L}_{\mathbf{1}}(\mathrm{BDH})$ has been shown to contain two I,3- $\beta$-glucanases (Marshall, I973): one specific for laminarin and the other a non-specific $\mathrm{I}, 3(4)-\beta$-glucanase. In the absence of $I, 4-\beta$-linkages in Candida glucans, the crude preparation was used since it showed no activity against lutean, pustulan, phosphomannan or yeast mannan. Some protease activity was present at $\mathrm{pH} 7 \cdot 5$.

Exo-1,3- $\beta$-glucanase from basidiomycete $\mathrm{QM} 806$. The organism was grown and the enzyme purified according to Houtari et al. (1968). It showed no protease, I,6- $\beta$-glucanase, $\alpha$ mannanase or phosphomannanase activities.

Chitinase. Attempts were made to purify the chitinase in the $S$. violaceus culture filtrates (see above). These confirmed the observation of Skujins, Potgeiter \& Alexander (1965) that two chitinases were present, but no complete separation from I,3- $\beta$-glucanase activity was achieved. The chitinases were unstable on freeze drying or storage in solution and accordingly chitinase from Calbiochem was used. This preparation contained some protease activity but was free of other enzyme activities.

\section{Enzyme assays}

Phosphatases. The method of Linhardt \& Walter (1963) was used, with 100 mM-citrate buffer $\mathrm{pH} 4^{\circ} \mathrm{O}$ for acid phosphatase, and $100 \mathrm{mM}$-glycine buffer $\mathrm{pH} 8.6$ containing I mM$\mathrm{MgCl}_{2}$ for alkaline phosphatase. One unit of enzyme activity hydrolysed I nmol $p$-nitrophenyl phosphate $\mathrm{h}^{-1}$ (mg protein $)^{-1}$.

Glucanases. Endo-I,3- $\beta$-glucanase and endo-1,6- $\beta$-glucanase were estimated by incubating 


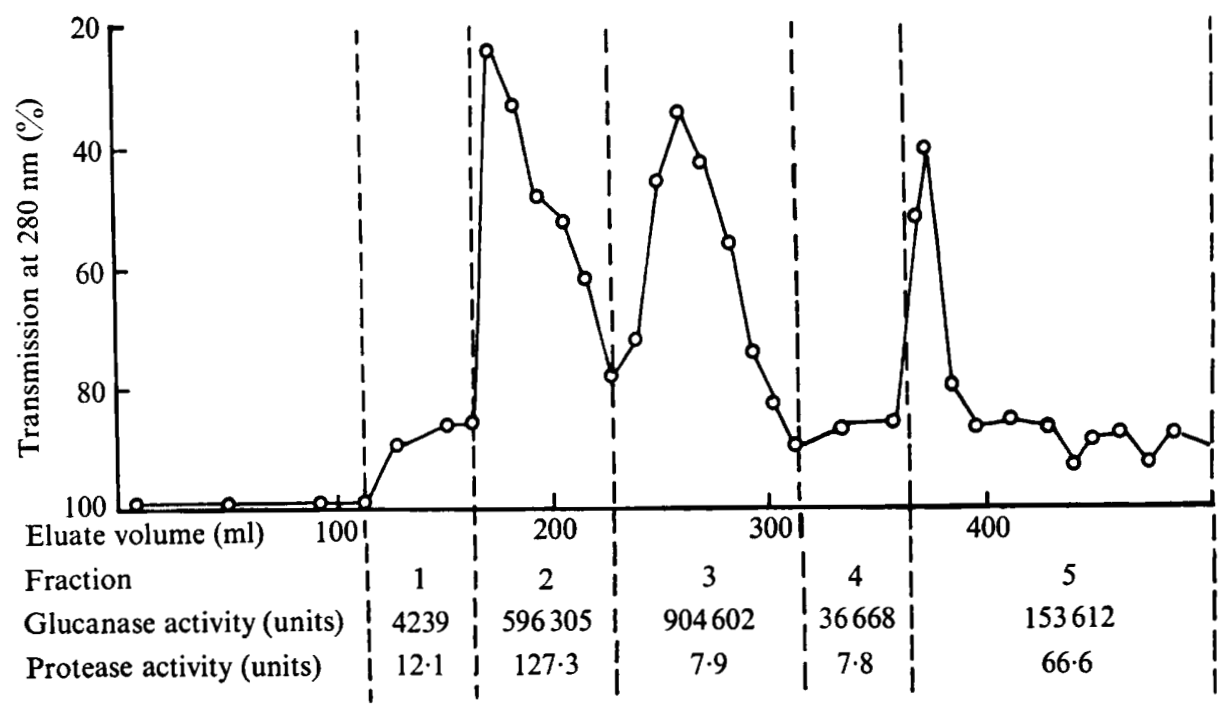

Fig. I. Culture filtrate from laminarin-grown Streptomyces violaceus. The 40 to $60 \%\left(\mathrm{NH}_{4}\right)_{2} \mathrm{SO}_{4}$ fraction of the culture filtrate was fractionated on DEAE-cellulose, and eluted with a phosphate gradient.

at $37^{\circ} \mathrm{C}$ for $\mathrm{I} \mathrm{h}$ in $\mathrm{I} \mathrm{ml}$ of either laminarin ( $\mathrm{I} \mathrm{mg}$ ) in $50 \mathrm{~mm}-\mathrm{Tris} / \mathrm{HCl}$ buffer, $\mathrm{pH} 7.5$, or pustulan ( $\mathrm{I} \mathrm{mg}$ ) in $50 \mathrm{~mm}$-sodium citrate/phosphate buffer, $\mathrm{pH} 5 \cdot 0$. Reaction was stopped by adding Somogyi reagent ( $\mathrm{I} \mathrm{ml}$ ) and the liberated reducing power was estimated by the Nelson-Somogyi method as $\mu \mathrm{g}$ glucose equivalent $\mathrm{h}^{-1}$. Exo-I,3- $\beta$-glucanase was similarly determined using $50 \mathrm{~mm}$-sodium acetate buffer $\mathrm{pH} 4.8$, containing $0.025 \%$ gelatin, and stopping the reaction by heating at $100{ }^{\circ} \mathrm{C}$ for $10 \mathrm{~min}$; glucose release was measured by the glucose oxidase method (Werner, Rey \& Wielinger, I970) as $\mu$ g glucose $\mathrm{h}^{-1}$.

Chitinase. The substrate, colloidal chitin (I mg ml-1; Berger \& Reynolds, 1958) in $50 \mathrm{~mm}$-phosphate buffer $\mathrm{pH} 6.3$, and enzyme (total vol. $5 \mathrm{ml}$ ) were incubated with shaking at $37^{\circ} \mathrm{C}$ for I h. Reaction was stopped by heating at $100{ }^{\circ} \mathrm{C}$ for $\mathrm{Io}$ min and released glucosamine was estimated as $\mu$ g glucosamine $\mathrm{h}^{-1}$.

Protease. Hydrolysis of $3 \%$ casein in either $50 \mathrm{~mm}-\mathrm{Tris} / \mathrm{HCl}$ buffer, $\mathrm{pH} 7.5$, or $100 \mathrm{~mm}-$ phosphate buffer $\mathrm{pH} 6.0$ (I ml) was measured by incubation at $37^{\circ} \mathrm{C}$ for $\mathrm{I} \mathrm{h}$. Unhydrolysed substrate was removed with $10 \%(\mathrm{v} / \mathrm{v})$ trichloroacetic acid $(3 \mathrm{ml})$ and the $E_{280}$ of the supernatant was measured. One unit of enzyme activity was defined as that which produced a unitary increase in $E_{\mathbf{2 8 0}} \mathrm{h}^{-1}$.

Treatment of Candida cells with hydrolytic enzymes. Cells from cultures grown for $4 \mathrm{~h}$ (10 $\mathrm{mg}$ dry $\mathrm{wt} \mathrm{ml}^{-1}$ ) or $\mathrm{I} 8 \mathrm{~h} \mathrm{(30} \mathrm{mg}^{2}$ dry $\mathrm{wt} \mathrm{ml}^{-1}$ ) were suspended in $800 \mathrm{~mm}$-mannitol/ $50 \mathrm{~mm}$-Tris/ $\mathrm{HCl}$ buffer, $\mathrm{pH} 7.5(20 \mathrm{ml})$, and incubated under nitrogen with shaking for $24 \mathrm{~h}$ at $37^{\circ} \mathrm{C}$; 12 mM-DTT and hydrolytic enzymes were added as required. When chitinase (Calbiochem) was added, cells and enzyme were used at one fifth of the normal concentration. Cell residues were separated by centrifuging at $800 \mathrm{~g}$ and retained for electron microscopy. Supernatants were freeze-dried and the residue $(\mathrm{I} / \mathrm{g} / \mathrm{I} 0 \mathrm{ml})$ was dissolved in $50 \mathrm{~mm}-\mathrm{Tris} / \mathrm{HCl}$ buffer, $\mathrm{pH} \mathrm{7.5}$, for analysis. Fractionation of this material on Sephadex G75, as described by Chattaway et al. (1974), gave qualitatively similar fractions from all treatments of the cells, with two main fractions being eluted. Fraction I was hydrolysed by the method of Johnston (1965); the only sugars present were glucose and mannose. The 
latter was estimated as the difference between total carbohydrate and glucose contents. Fraction 2 contained mannitol from the suspending fluid in addition to glucose, mannose and ribose. After hydrolysis, the mannitol interfered strongly with the total carbohydrate estimation, and the ribose was largely destroyed. Thus total reducing sugar and glucose were measured and the difference taken as a measure of mannose.

Chemical estimations. Total carbohydrate was estimated by the method of Dubois et al. (1956), and correcting for the presence of mannitol; total reducing sugar by the method of Somogyi (1952); ribose according to Herbert, Phipps \& Strange (197I); glucose by the glucose oxidase method (Werner et al., 1970) and glucosamine according to Herbert et al. (197I). Protein was estimated by the method of Lowry et al. (195I), but when interfering substances such as sugars or thiols could not be removed it was determined according to Warburg \& Christian (1942).

Electron microscopy. Candida cells were fixed in 100 mM-phosphate buffer $\mathrm{pH} 7 \cdot 4$ containing $2.5 \%$ (v/v) glutaraldehyde (Eastman; electron microscopy grade), washed with buffer, stained with $\mathrm{OsO}_{4}(2 \%, w / v)$ for $\mathrm{I} \mathrm{h}$, dehydrated in a graded series of ethanol concentrations from 40 to $100 \%$, embedded in Epon 90, sectioned on a LKB Ultratome III, stained with lead citrate, and photographed on $35 \mathrm{~mm}$ film using a Philips EM300 microscope.

Estimation of protoplasts. The decrease in $E_{660}$ I0 min after dilution of a cell suspension ( $\mathrm{I}: 6, \mathrm{v} / \mathrm{v}$ ) with distilled water was used (Baird \& Cunningham, I97I). Since this method estimates all osmotically fragile cells, true protoplasts were also counted by phase-contrast microscopy.

\section{RESULTS}

Cells from cultures grown for $4 \mathrm{~h}$ and $\mathrm{I} 8 \mathrm{~h}$ as blastospores or as mycelium were exposed to DTT and hydrolytic enzymes under conditions which would stabilize the protoplasts produced. The treated cells were examined by electron microscopy to detect any changes in the cell surface and the supernatants were examined for the release of acid phosphatase and other components of the surface. The cytoplasmic membrane was shown to be intact by electron microscopy and by the absence of alkaline phosphatase in the supernatants. This enzyme is intracellular because it cannot be assayed using intact cells and is not associated with washed wall preparations.

\section{Cell surface acid phosphatase activity and its release}

Acid phosphatase, associated with the cell surface, can be demonstrated simply by incubation with a suitable substrate, and washed wall preparations also show appreciable activity (Chattaway, Odds \& Barlow, 1971). Small amounts of activity were released by incubation of cells in buffer and the effect of agents which disrupt surface components was to increase both the total activity detected and the proportion of the activity released into the supernatant (Table I). DTT increased the proportion of activity released by 30 to $50 \%$ and the Cytophaga $L_{1}$ enzyme increased this figure by approximately $25 \%$, except in the case of mycelium from $4 \mathrm{~h}$ cultures where virtually all the activity was released. The effect of the preparations from $S$. violaceus was less marked, giving increases of 5 to $20 \%$ above that achieved with DTT, except that mycelium from $4 \mathrm{~h}$ cultures again gave an appreciably higher result. It made little difference whether the second disrupting agent was I,3- $\beta$-glucanase alone or combined with chitinase or protease, or chitinase and protease in the absence of the glucanase. The effectiveness of this last pair of enzymes may have been 


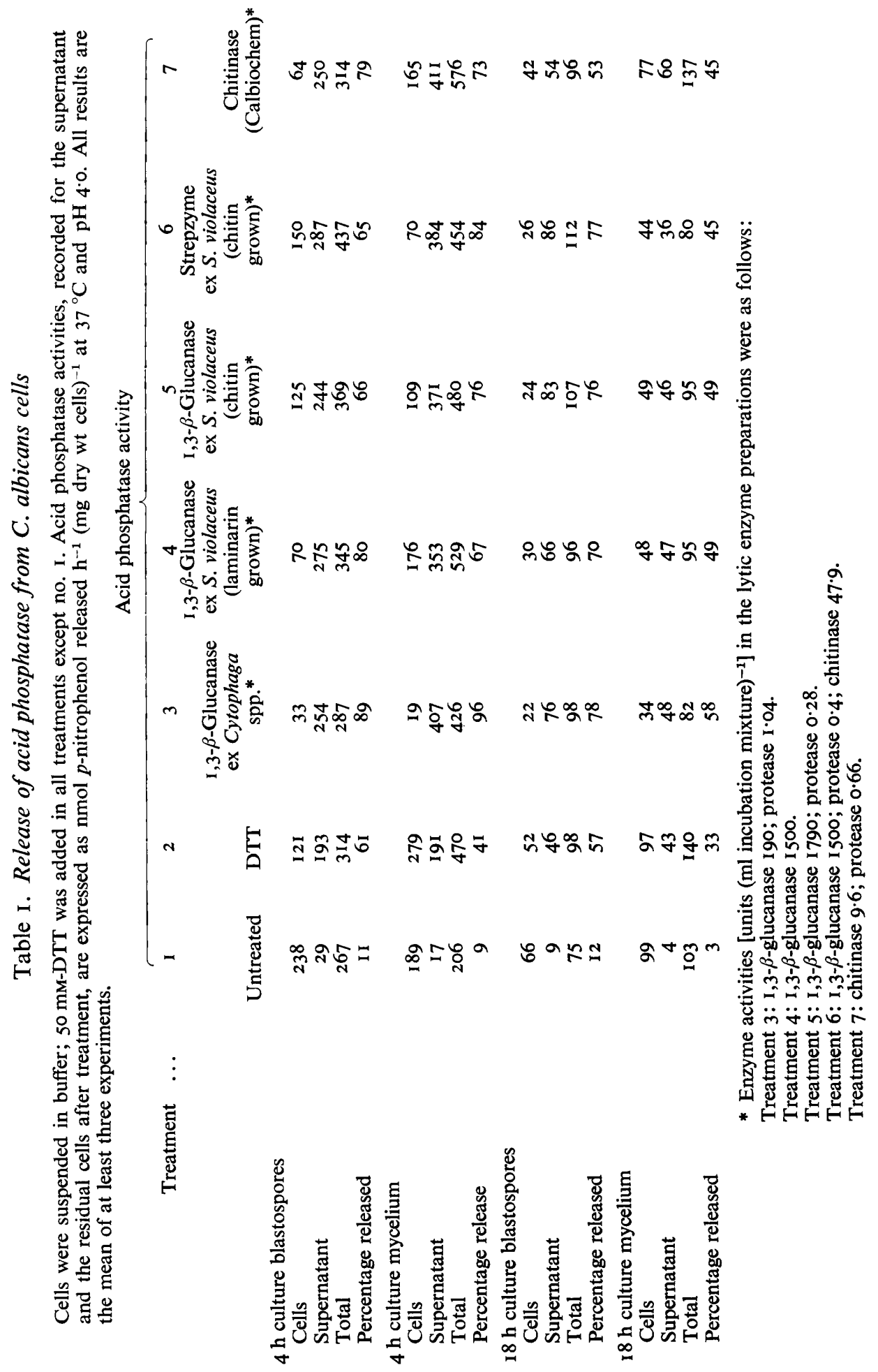


Table 2. Release of carbohydrate from the cell surface of C. albicans

After different treatments of the cells (see Table I), the supernatant was freeze-dried and fractionated on Sephadex G75. Results are given for fraction I. Values \pm S.D. have been corrected for the polysaccharide present in the solutions before the addition of cells, and are the means of at least three determinations. Values for $\mathrm{mg}$ glucose equivalent ( $\mathrm{g}$ freeze-dried supernatant $)^{-1}$ are equivalent to $200 \mathrm{mg}$ dry wt cells; those for $4 \mathrm{~h}$ cultures were determined on supernatant volumes equivalent to $66.7 \mathrm{mg}$ dry wt cells and have been corrected to $200 \mathrm{mg}$ dry wt.

\begin{tabular}{|c|c|c|c|c|}
\hline \multirow{3}{*}{$\begin{array}{c}\text { Treatment } \\
\text { (see Table I) }\end{array}$} & \multicolumn{4}{|c|}{$\begin{array}{l}\text { Total carbohydrate } \\
\left.\text { [mg glucose equivalent ( } \mathrm{g} \text { freeze-dried supernatant })^{-1}\right]\end{array}$} \\
\hline & \multicolumn{2}{|c|}{ Blastospore } & \multicolumn{2}{|c|}{ Mycelium } \\
\hline & $4 \mathrm{~h}$ culture & I $8 \mathrm{~h}$ culture & 4 h culture & I $8 \mathrm{~h}$ culture \\
\hline I & $4.08 \pm 0.61$ & $1.97 \pm 0.04$ & $4.99 \pm 0.06$ & $2.59 \pm 0.16$ \\
\hline 2 & $15.55 \pm 0.90$ & $9.33 \pm 0.23$ & $9.07 \pm 0.73$ & $2.98 \pm 0.18$ \\
\hline 3 & $44 \cdot 33 \pm I \cdot I I$ & $107.81 \pm 30.2$ & $64.95 \pm 7.47$ & $80.44 \pm 7.24$ \\
\hline 4 & $20.41 \pm 4.29$ & $16.93 \pm I \cdot 22$ & $31.43 \pm 2.86$ & $25.92 \pm 1.89$ \\
\hline 5 & $21 \cdot 06 \pm 3 \cdot 16$ & $9.07 \pm 0.62$ & $3 I \cdot I \pm I \cdot 93$ & $34.47 \pm 2.62$ \\
\hline 6 & $42 \cdot 59 \pm 5 \cdot 2$ & $57 \cdot 27 \pm 1 \cdot 0$ & $42 \cdot 05 \pm 6 \cdot 73$ & $6 \mathrm{I} \cdot 59 \pm 5 \cdot 73$ \\
\hline 7 & $9.07 \pm 0.38$ & $18.58 \pm 4.87$ & $30 \cdot 33 \pm 1 \cdot 73$ & $16.54 \pm 2 \cdot 20$ \\
\hline
\end{tabular}

enhanced by activity of an endogenous $\beta$-glucanase. The release of the phosphatase from I $8 \mathrm{~h}$ culture mycelium was lower for all treatments compared with that from mycelium at $4 \mathrm{~h}$ and blastospores at $4 \mathrm{~h}$ and $\mathrm{I} 8 \mathrm{~h}$.

\section{Release of cell-wall glycopeptide material}

Fractionation on Sephadex $G_{75}$ gave qualitatively the same two fractions from all treatments.

Fraction I. This was predominantly polysaccharide. Further fractionation on Sephadex G200 gave a peptide containing a fraction free from carbohydrate. The principal polysaccharide material, associated with a low peptide content, was not retarded by the gel and remained unfractionated (molecular weight $>800000$ ). This fraction contained all the acid phosphatase activity released from the cells. Variation in the total carbohydrate' content with the different treatments is shown in Table 2. The small release on incubation in buffer was increased in the presence of DTT. This effect was more marked with blastospores than with mycelium. Treatments 3 and 6 (Table I), which gave rise to protoplasts, released most material; the release from cells from $\mathrm{I} 8 \mathrm{~h}$ cultures was greater than that from $4 \mathrm{~h}$ culture cells. Treatments 4,5 and 7 (Table I), which showed greater surface disruption than that caused by DTT, also released more fraction I, and this release was more marked from mycelium from both $4 \mathrm{~h}$ and $\mathrm{I} 8 \mathrm{~h}$ cultures than from the corresponding blastospores.

The proportions of glucose and mannose in the above preparations showed no striking variations; mannose formed 60 to $80 \%$ of the carbohydrate present suggesting that the different treatments released material of approximately the same carbohydrate content.

Fraction 2. This fraction had a molecular weight $<\mathrm{I} 2500$ which did not vary with the different treatments, it was devoid of acid phosphatase activity, it had only a low carbohydrate content, and its u.v. spectrum showed maxima at $260 \mathrm{~nm}$ (except with treatment 7 ) and $280 \mathrm{~nm}$. The high mannitol content made carbohydrate estimations difficult and when corrections were made these showed little significant variation between the treatments. There was a higher proportion of the material with an absorption maximum at $260 \mathrm{~nm}$ in cells from $\mathrm{I} 8 \mathrm{~h}$ cultures than in those from $4 \mathrm{~h}$ cultures after treatment 6 (Table I), but not 

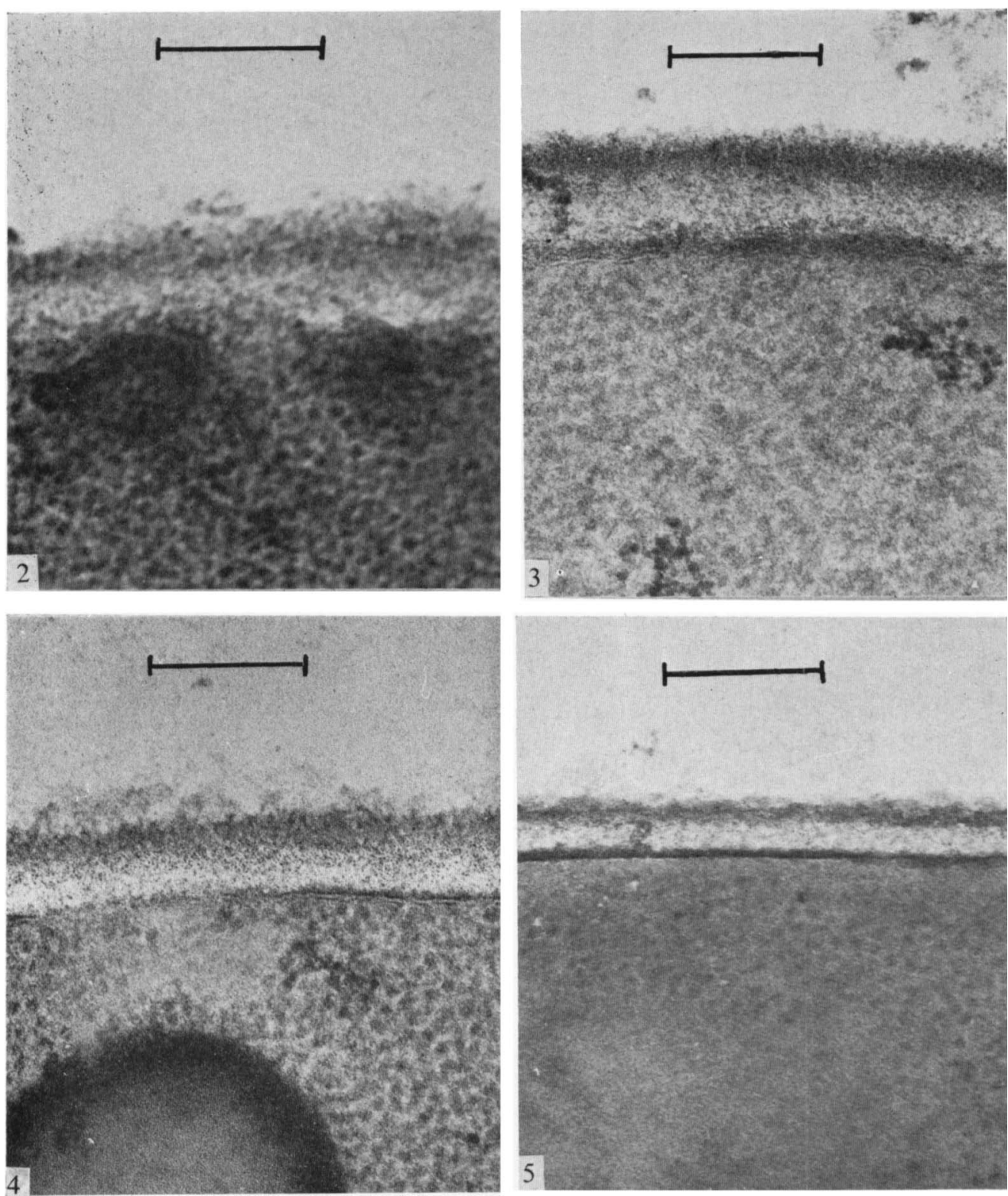

Figs 2 to 5. Normal cells showing the differing widths of blastospore and mycelial walls and the relatively electron-dense outer layers merging into an electron-transparent layer separated by a narrow electron-dense layer from the cytoplasmic membrane. Fig. 2, blastospore from a $4 \mathrm{~h}$ culture. Fig. 3, blastospore from an $18 \mathrm{~h}$ culture. Fig. 4, mycelium from a $4 \mathrm{~h}$ culture. Fig. 5, mycelium from an $\mathrm{I} 8 \mathrm{~h}$ culture. Bar marker represents $0.2 \mu \mathrm{m}$.

after treatment 3 , and the reverse was found for material absorbing at $280 \mathrm{~nm}$. This again emphasizes the differing effects of these treatments which both form protoplasts.

\section{Electron microscopy of the cell surface}

Preliminary examination of untreated cells of both morphological forms confirmed the multilayered wall structure described by Cassone et al. (1973) and that the mycelial wall 

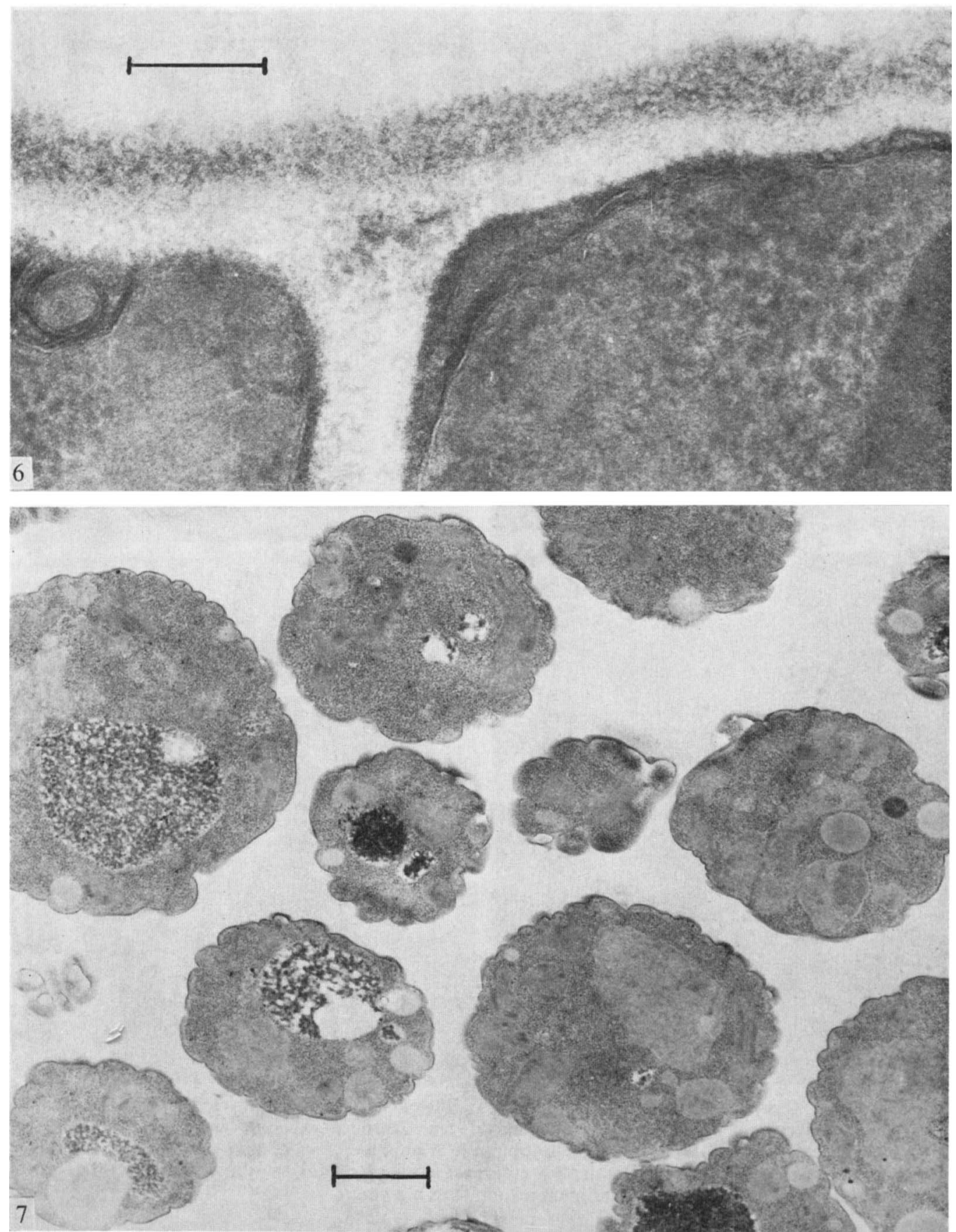

Fig. 6. The effect of DTT ( $12 \mathrm{~mm}$ ) on mycelium from an $18 \mathrm{~h}$ culture. The outer electron-dense layers have become more diffuse indicating a loosening of the wall components. The effect of the reagent can also be seen in the area of the septum. Bar marker represents $0 \cdot 2 \mu \mathrm{m}$.

Fig. 7. Protoplasts prepared from blastospores from an $18 \mathrm{~h}$ culture treated with Streptomyces violaceus enzyme preparation and DTT. Bar marker represents $\mathrm{I} \mu \mathrm{m}$. 


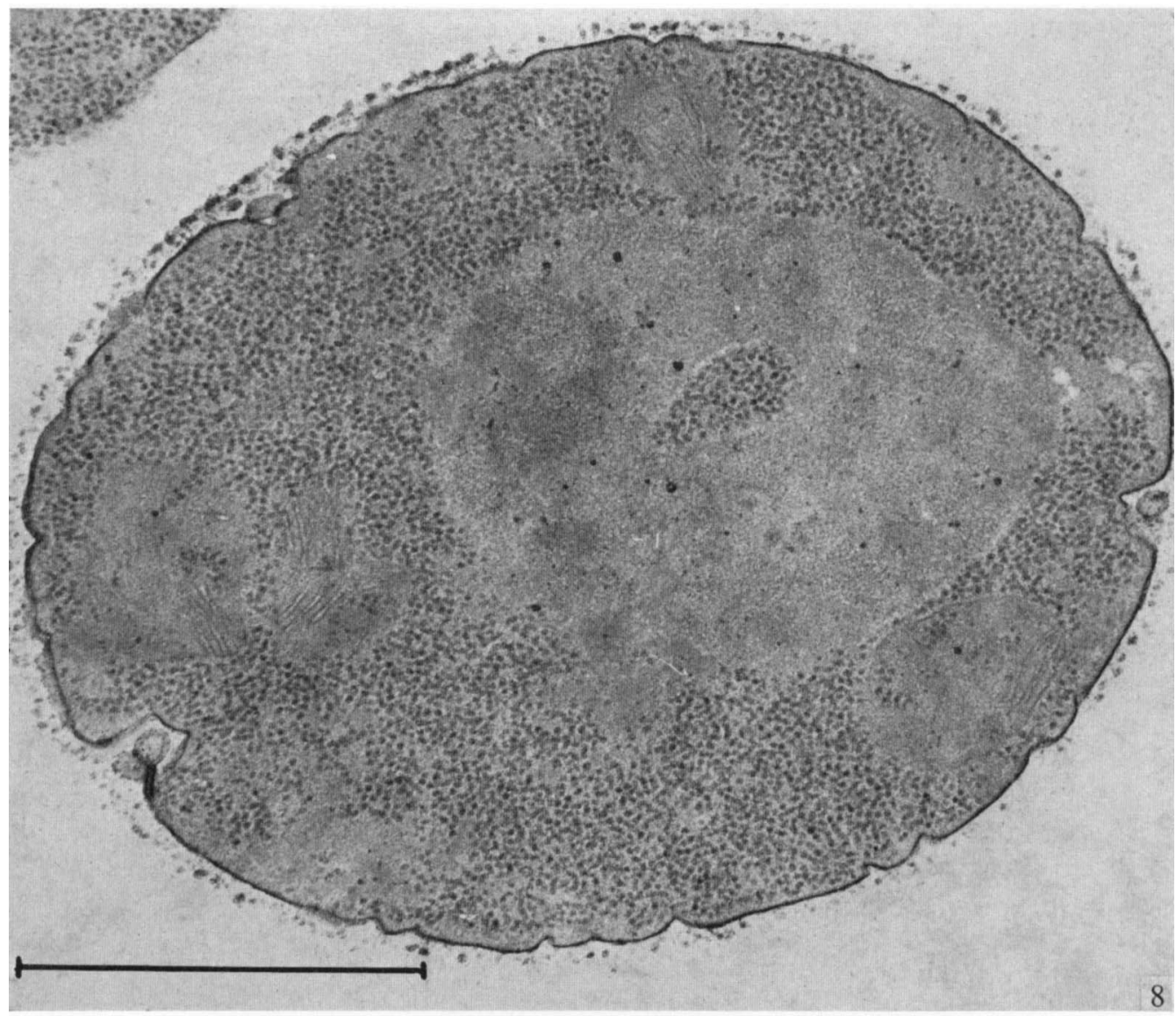

Fig. 8. Spheroplast produced by the action of purified 1,3- $\beta$-glucanase from Streptomyces violaceus and DTT on a blastospore from an $18 \mathrm{~h}$ culture. The outer layers of the wall have been removed and the inner layers damaged. Significant amounts of these layers remain but the cell was osmotically fragile. Bar marker represents $\mathbf{I} \mu \mathrm{m}$.

was thinner than that of blastospores at both $4 \mathrm{~h}$ and $\mathrm{I} 8 \mathrm{~h}$ (Figs 2 to 5). DTT probably reduces disulphide bonds, particularly in the outer glycoprotein layer, leading to a loosening of this layer and more ready penetration by lytic enzymes. This effect was observed in both forms and is illustrated in Fig. 6 for mycelium where the reagent is also seen to have penetrated into the area of septum formation.

Protoplasts were produced in $90 \%$ yield (Fig. 7), in the presence of DTT, by the action of either the Cytophaga lytic enzyme $\mathrm{L}_{1}$ (treatment 3, Table $\mathrm{I}$ ), or the crude preparation from $S$. violaceus (treatment 6 , Table I). The use of the purified I, 3- $\beta$-glucanase (treatment 4 , Table I) had no demonstrable effect on mycelium from either $4 \mathrm{~h}$ or $\mathrm{I} 8 \mathrm{~h}$ cultures and caused only partial degradation of the outer layers of the wall of blastospores, yielding spheroplasts and not protoplasts (Fig. 8). The inclusion of a protease with the glucanase (treatment 5, Table I) led to the complete removal of the outer layer of the blastospore walls and again spheroplasts were obtained. Mycelial preparations also showed this effect but since the inner layers of the wall apparently remained intact there was no change of shape (Fig. 9). The presence of the chitinase in the $S$. violaceus preparation (together with the $1,3-\beta$-glucanase, protease and DTT) appears to be essential for the production of 

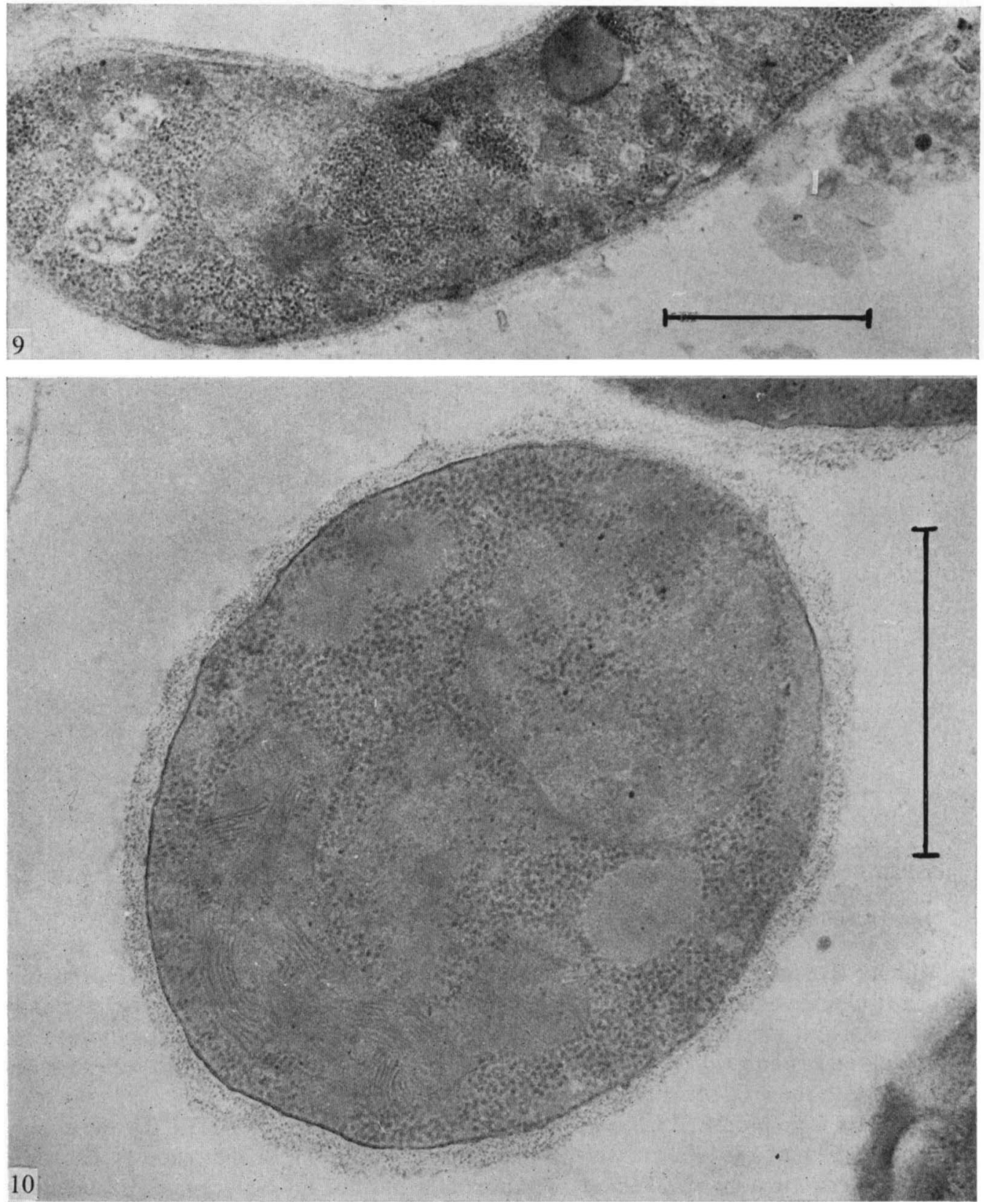

Fig. 9. The action of $1,3-\beta$-glucanase, protease and DTT on mycelium from a $4 \mathrm{~h}$ culture. The outer layers of the wall have been removed, with some of the inner electron-transparent layer, but the shape is maintained. The preparation was osmotically fragile. Bar marker represents I $\mu \mathrm{m}$.

Fig. 10. The action of chitinase, protease and DTT on a blastospore from an $18 \mathrm{~h}$ culture. The outermost layers have been removed. Appreciably more of the inner layers remain (cf. Fig. 5), but the preparation was osmotically fragile. Bar marker represents I $\mu \mathrm{m}$. 
protoplasts. Although the glucan of $C$. albicans has a higher proportion of $\mathrm{I}, 6-\beta$-linkages than the glucan of Saccharomyces cerevisiae (Yu et al., I $1967 a$ ), it is only the rupture of the $\mathrm{I}, 3-\beta$-linkages which is required in both organisms for the release of protoplasts.

The chitinase preparation (treatment 7 , Table I) removed the outer layer of the wall in $4 \mathrm{~h}$ culture mycelium with no change in shape. Similarly in $\mathrm{I} 8 \mathrm{~h}$ culture blastospores, the outer layer was removed and spheroplasts were formed (Fig. I0). The chitinase preparation had no visible effect on $4 \mathrm{~h}$ culture blastospores or $18 \mathrm{~h}$ culture mycelium.

\section{DISCUSSION}

Blastospores of $C$. albicans resemble those of $S$. cerevisiae in the qualitative composition of the cell surface. Studies on $S$. cerevisiae have led to the concept that the wall consists of an outer, electron-dense layer, comprising mainly mannan and protein, enclosing an electron-transparent layer containing glucan and chitin with some protein. This inner layer is separated from the cytoplasmic membrane by a narrow electron-dense layer which may be partly responsible for the rigidity of the cell structure, and which probably contains protein and chitin.

Lampen (1968) and Kidby \& Davies (1970) postulated possible arrangements of the various polymers in the wall structure and accounted for the retention and release of enzymes such as invertase and acid phosphatase. Treatment with thiol reagents, as well as releasing enzymes, also promotes protoplast formation by permitting greater access of lytic enzymes to their substrates contained in the surface structures.

Cassone et al. (1973) distinguished five layers in both blastospores and mycelium of C. albicans and recorded changes in different layers during germ-tube development. In addition to the three main layers seen in Saccharomyces spp., they showed an outermost floccular layer and a fibrillar layer between the outer electron-dense layer and the electrontransparent layer, often infiltrating into this latter structure. The present study has confirmed these observations (Figs 2 to 5), and also that the mycelial wall is only approximately half the thickness of the blastospore wall. The appearance of discrete layers in electron micrographs does not necessarily imply distinctive chemical composition, and the material solubilized by all the treatments used had similar properties but varied considerably in amount according to the particular treatment. This suggests that while the proportions of mannan, glucan and protein may vary in different parts of the cell surface, there is a degree of association between them and chitin, such that disruption by DTT or the lytic enzymes results in the release of similar material.

The action of DTT is necessary for any extensive degradation by lytic enzymes to occur, which emphasizes the important protective role of the protein components. The addition of the $1,3-\beta$-glucanase from $S$. violaceus results in the release of increased quantities of the mannan-glucan-peptide complex from both blastospores and mycelium. This treatment resulted in loss of the outer blastospore wall layers, but had no demonstrable effect on the appearance of mycelium, indicating differences in the wall structure between the two forms. The addition of a protease resulted in the loss of the outer layers of the wall from both blastospores and mycelium, the rigidity of the cell structures being maintained. The inclusion of a chitinase as well resulted in protoplast production from both forms and from both exponential and early-stationary-phase cells. This confirms the importance of chitin in the structure of the inner layers of the wall and the observation of Gale et al. (1975) that the lytic enzyme from $S$. violaceus grown on chitin would form spheroplasts from exponential-phase cells. These authors found that late-stationary-phase cells also required 
an enzyme obtained from growth of the streptomycete on Candida cells for spheroplast formation. However, the production of protoplasts using the Cytophaga lytic enzyme $L_{1}$ which contained I,3- $\beta$-glucanase and protease but no chitinase, suggests that the actions of this enzyme and of the $1,3-\beta$-glucanase from $S$. violaceus may be different, in the former case being sufficiently extensive to allow loss of all layers of the wall without disruption of the chitin. This possibility is supported by the fact that while both glucanases yielded oligosaccharides from laminarin (average chain length 15 glucose residues), the $\mathrm{L}_{1}$ enzyme completed its action in I $\mathrm{h}$ while the $S$. violaceus enzyme required $\mathrm{I} 8 \mathrm{~h}$ (unpublished results). This effect coupled with the extensive I,6- $\beta$-linkages in the Candida glucan may well result in different degrees of disruption of the wall by the two enzymes.

$\mathrm{I}, 3-\beta$-Glucanase is essential for major changes in the wall to be effected, but significant release of the glucan-mannan-peptide complex and also acid phosphatase occurred with the chitinase (Calbiochem) preparation. The presence of a low protease activity makes it difficult to determine whether or not both enzymes are required for these effects and their action may have been assisted by the presence of endogenous glucanase.

The release of acid phosphatase as shown in Table I suggests a more complex distribution of the enzyme on the surface than its simple retention within the protein-polysaccharide network of the outer layers. In preparations containing $90 \%$ protoplasts up to $20 \%$ of the activity is still retained by the protoplasts from $\mathrm{I} 8 \mathrm{~h}$ culture blastospores and the exponentialphase cells of both forms and up to $50 \%$ by the $\mathrm{I} 8 \mathrm{~h}$ culture mycelium. This result indicates association of some of the enzyme with the cytoplasmic membrane and a difference in its distribution between the older mycelium and other cells.

We thank the Wellcome Trust for a maintenance grant to one of us (S.S.) and for a grant towards the cost of this work.

\section{REFERENCES}

Bacon, J. S. D., Gordon, A. H., Jones, D., TAylor, I. F. \& Webley, D. M. (1970). The separation of $\beta$-glucanases produced by Cytophaga johnsonii and their role in the lysis of yeast cell walls. Biochemical Journal 120, 67-78.

BaIRD, J. K. \& CUNnINGHAM, W. L. (1971). Formation of yeast protoplasts by using an enzyme preparation from Cytophaga. Biochemical Journal 125, 32P-33P.

Berger, L. R. \& REYNOLDS, D. M. (1958). The chitinase system of a strain of Streptomyces griseus. Biochimica et biophysica acta 29, 522-534.

Cassone, A., Simonetti, H. \& Strippoli, V. (I973). Ultrastructural changes in the wall during germ-tube formation from blastospores of Candida albicans. Journal of General Microbiology 77, 417-426.

Chattaway, F. W., Holmes, M. R. \& Barlow, A. J. E. (I968). Cell wall composition of the mycelial and blastospore forms of Candida albicans. Journal of General Microbiology 51, 367-376.

Chattaway, F. W., Odds, F. C. \& Barlow, A. J. E. (I97I). An examination of the production of hydrolytic enzymes and toxins by pathogenic strains of Candida albicans. Journal of General Microbiology 67, 255-263.

Chattaway, F. W., Shenolikar, S. \& Barlow, A. J. E. (1974). The release of acid phosphatase and polysaccharide- and protein-containing components from the surface of the dimorphic forms of Candida albicans by treatment with dithiothreitol. Journal of General Microbiology 83, 423-425.

Domanski, R. E. \& Miller, R. E. (I968). Use of a chitinase complex and $\beta$-(I,3)-glucanase for spheroplast production from Candida albicans. Journal of Bacteriology 96, 270-27I.

Dubois, M., Gilles, K. A., Hamilton, J. K., Rebers, P. A. \& Smith, F. (I956). Colorimetric method for determination of sugar and other substances. Analytical Chemistry 28, 350-356.

Elorza, M. V., Ruiz, E. M. \& Villanueva, J. R. (I966). Production of yeast cell-wall lytic enzymes on a semi-defined medium by a Streptomyces. Nature, London 210, 442-443.

GALE, G. R. (1963). Cytology of Candida albicans as influenced by drugs acting on the cytoplasmic membrane. Journal of Bacteriology 86, I 5 I-I 57.

Gale, E. F., Johnson, A. M., KerRidge, D. \& KoH, T. Y. (1975). Factors affecting the changes in amphotericin sensitivity of Candida albicans during growth. Journal of General Microbiology 87, $20-36$. 
Herbert, D., Phipps, P. J. \& Strange, R. E. (1971). Methods in Microbiology, vol. 5B, pp. 284-29i. New York: Academic Press.

Houtari, F. I., Nelson, T. E., Smith, F. \& Kirkwood, S. (1968). Purification of an exo- $\beta$-D-(I $\rightarrow 3)-$ glucanase from Basidiomycete species QM806. Journal of Biological Chemistry 243, 952-956.

Johnston, I. R. (1965). The composition of the cell wall of Aspergillus niger. Biochemical Journal 96, $65 \mathrm{I}-658$.

KESSLER, G. \& NICKERSON, W. J. (1959). Glucomannan-protein complexes from cell wall of yeasts. Journal of Biological Chemistry 234, 228I-2285.

KIDBY, D. K. \& DAVIES, R. (1970). Invertase and disulphide bridges in the yeast wall. Journal of General Microbiology 6r, 327-333.

LAMPEN, J. O. (1968). External enzymes of yeast: their nature and formation. Antonie van Leeuwenhoek 34, I-I 8 .

LinhardT, K. \& Walter, K. (I963). Phosphatases. In Methods of Enzymatic Analysis, pp. 783-785. Edited by H. U. Bergmeyer. New York: Academic Press.

Lowry, O. H., Rosebrough, N. J., Farr, A. L. \& Randall, R. J. (195I). Protein measurement with the Folin phenol reagent. Journal of Biological Chemistry I93, 265-275.

McLellan, W. L. \& Lampen, J. O. (I968). Phosphomannanase (PR-Factor), an enzyme required for the formation of yeast protoplasts. Journal of Bacteriology 95, 967-974.

Marshall, J. J. (1973). Behaviour of $\beta$-glucan hydrolases on ion-exchangers. Analytical Biochemistry 53, I $19 \mathrm{I}-\mathrm{I} 98$.

Skujins, J. J., Potgeiter, H. J. \& AleXANder, M. (1965). Dissociation of fungal cell walls by a Streptomycete chitinase and $\beta-(\mathrm{I}, 3)$-glucanase. Archives of Biochemistry and Biophysics III, 358-364.

Somogyı, M. (1952). Notes on sugar determination. Journal of Biological Chemistry 195, 19-23.

WARBURG, O. \& CHRISTIAN, W. (1942). Isolation and crystallisation of enolase. Biochemische Zeitung 3ro, $384-42$ I.

WerNer, W., Rey, H. G. \& Wielinger, H. (1970). Über die Eigenschaften eines neuen Chromogens für die Blutzuckerbestimmung nach der GOD/POD-Methode. Zeitschrift für Analytische Chemie 252, 224-228.

Yu, R. J., Bishop, C. T., COOPER, F. P., BLANK, F. \& HASENCLeVER, H. F. (1967a). Glucans from Candida albicans (seroptye B) and from Candida parapsilosis. Canadian Journal of Chemistry 45, 2264-2267.

Yu, R. J., Bishop, C. T., COOPER, F. P., Hasenclever, H. F. \& Blank, F. (1967 b). Structural studies of mannans from Candida albicans (serotypes A \& B), Candida parapsilosis, Candida stellatoidea and Candida tropicalis. Canadian Journal of Chemistry 45, 2205-22I I. 